\title{
Circadian Rhythm of Urinary pH in Man with and without Chronic Antacid Administration*
}

\author{
J. W. Ayres**, D. J. Weidler, J. MacKichan, and J. G. Wagner*** \\ College of Pharmacy and Upjohn Center for Clinical Pharmacology, The University of Michigan, Ann Arbor, Michigan, USA
}

Summary. In normal human volunteers, when urinary $\mathrm{pH}$ was plotted versus time, the circadian sine-wave type curve was not altered by chronic administration of a commercially available suspension ${ }^{1}$ containing a mixture of magnesium and aluminum hydroxides, although the antacid perturbed the entire curve in a more alkaline direction. A single dose of the antacid had little effect on urinary $\mathrm{pH}$. There was a highly significant linear relationship between the change in hydrogen ion concentration during chronic antacid treatment and the initial control urinary hydrogen ion concentration, but there was no significant correlation between change in urinary $\mathrm{pH}$ and initial control urinary $\mathrm{pH}$ as has been previously reported. The above results were based on the evaluation of the hydrogen ion concentrations of 1562 separate urine samples collected from 24 normal subjects in a three treatment crossover study. It is recommended that: (1) research studies involving drug-drug interactions with antacids be designed to consider the effect of the antacid on the circadian rhythm of urinary $\mathrm{pH}$, and (2) $\mathrm{pH}$ values not be averaged as commonly reported in the literature, but rather the $\mathrm{pH}$ values be converted to hydrogen ion concentrations before statistical analysis.

Key words: Circadian urinary $\mathrm{pH}$, chronic antacid, statistical analysis.

The excretion of alkaline urine following meals was reported as early as 1845 (Jones) and diurnal varia-

\footnotetext{
* Supported by a contract from McNeil Laboratories, Inc.

** Present address: School of Pharmacy, Oregon State University, Corvallis, Oregon, 97331, USA.

*** Please address reprint requests to: Dr. John G. Wagner, Upjohn Center for Clinical Pharmacology, The University of Michigan Medical Center, Ann Arbor, Michigan, 48109, USA.

${ }^{1}$ Maalox ${ }^{\circledR}$ (William H. Rorer, Inc.).
}

tions or circadian rhythms in urinary acidity have been subsequently documented (Burnett and Blume, 1938; Stanbury and Thompson, 1951; Mills and Stanbury, 1951; Elliot et al., 1958). A spontaneous "morning alkaline tide" has been shown to exist for normal subjects at rest (without water or food) during which the early morning urine is acidic for about $2 \mathrm{~h}$ after waking. This period is followed by the production of a more and more alkaline urine with a maximum output of the alkali about $5 \mathrm{~h}$ after waking (Burnett and Blume, 1938). The spontaneous alkali excretion generally continues several hours and then returns to the initial level of urinary acid excretion in the late afternoon or evening. The morning or "matutinal" alkaline tide occurs with or without breakfast (Burnett and Blume, 1938) and the nocturnal acidification of the urine is not due to night-time starvation (Stanbury and Thompson, 1951).

The rate of renal excretion of weak acids and bases is often related to the $\mathrm{pH}$ of the urine. Dettli and Spring (1966) have reviewed the literature on this subject and demonstrated that the half-life of sulfasymazine increased from $13.5 \mathrm{~h}$ during the day to $35 \mathrm{~h}$ during the night; it was proposed that the variation in half-life for this drug may have been due to diurnal changes in the $\mathrm{pH}$ of urine and/or a concomitant change in the $\mathrm{pH}$ of extracellular fluids. The urinary excretion rate of amphetamine has also been shown to correlate with the circadian rhythm of urinary pH (Beckett and Rowland, 1964). Maintenance of either an acidic ( $\mathrm{pH} \mathrm{5.0)}$ or basic ( $\mathrm{pH}$ 8.0) urine by administration of ammoniumchloride or sodium bicarbonate was associated with a decrease or increase, respectively, in half-life of the drug.

The effect of the chronic administration of several antacids on the $\mathrm{pH}$ of urine has recently been re- 
Table 1. Study design for three treatment crossover with 24 subjects and six treatment sequences with details of treatments

\begin{tabular}{lllll}
\hline & & \multicolumn{3}{l}{ Treatment } \\
\cline { 3 - 5 } Group & Subject Number & Week I & Week II & Week III \\
\hline I & $3,9,15,22$ & A & B & C \\
II & $1,11,13,20$ & C & A & B \\
III & $2,12,14,21$ & B & C & A \\
IV & $4,7,16,24$ & A & C & B \\
V & $5,8,17,23$ & B & A & C \\
VI & $6,10,18,19$ & C & B & A \\
\hline
\end{tabular}

\section{Treatment A: No antacid}

Treatment $B$ : The subjects received a $20 \mathrm{ml}$ dose of Maalox 3 magnesium and aluminum hydroxides suspension four times per day for 4 days at 8:00 a.m., 1:00 p.m., 6:00 p.m. and 11:00 p. $m$. The container was rinsed two times with $20 \mathrm{ml}$ volumes of water and the contents consumed each time.

Treatment $C$ : Twenty $\mathrm{ml}$ of Maalox ${ }^{*}$ magnesium and aluminum hydroxides suspension were administered and the container rinsed two times with $20 \mathrm{ml}$ volumes of water and the contents consumed each time, at 8:00 a.m. on day 4 only.

ported (Gibaldi et al., 1974; Gibaldi et al., 1975) and the mean urinary $\mathrm{pH}$ during the collection interval reportedly increased about $0.86 \mathrm{pH}$ units following administration of aluminium and magnesium hydroxide suspension. Urine samples were collected only from 8:00 a.m. $-4: 00 \mathrm{p} . \mathrm{m}$., hence, information relative to the effect of the antacid on the circadian rhythm of urinary $\mathrm{pH}$ was not available.

This paper reports the effects of a single dose and of chronic doses of a commonly used antacid on the circadian rhythm of urinary $\mathrm{pH}$ and on pooled 24- $\mathrm{h}$ urine hydrogen ion concentration values. The results are compared to literature reports of the effects of antacids on urine $\mathrm{pH}$. The importance of using hydrogen ion concentration for statistical analysis rather than following the common practice of averaging $\mathrm{pH}$ values is demonstrated.

\section{Materials and Methods}

Twenty-four healthy male volunteers (aged 21-43 years; weight $66-89 \mathrm{~kg}$ ) participated in a threetreatment crossover study utilizing all 6 possible treatment sequences, as shown in Table 1. Subjects maintained their usual dietary habits except that no food was allowed from 8:00 p.m. of day 3 until 12:00 noon of day 4. Each subject collected all urine for five days during each treatment (from Monday 8:00 a.m. until Saturday at 8:00 a.m.). Micturition was according to natural impulse and was not scheduled. The total volume of each micturition was collected in separate containers and the time of micturition recorded. All samples were refrigerated until the time of $\mathrm{pH}$ determination; then samples were allowed to equilibrate with room temperature and the $\mathrm{pH}$ was determined with a $\mathrm{pH}$ meter ${ }^{2}$ which was standardized with 3 buffer solutions each day. All $\mathrm{pH}$ measurements were completed within $24 \mathrm{~h}$ of micturition and the effect of refrigeration on $\mathrm{pH}$ values was assessed. The effects of antacid on circadian urinary $\mathrm{pH}$ and mean urinary hydrogen ion concentrations for 24-h urine collections were determined.

\section{Results}

Storage of unrefrigerated urine for $24 \mathrm{~h}$ showed no change in mean hydrogen ion concentration although individual hydrogen ion concentrations changed corresponding to urinary $\mathrm{pH}$ changes over the range $0.08-0.28 \mathrm{pH}$ units. The hydrogen ion concentration of individual refrigerated urine samples remained unchanged after $24 \mathrm{~h}$. Parallel measurements were carried out by different operators on some urine samples with a different $\mathrm{pH}$ meter and the results never differed by more than $0.05 \mathrm{pH}$ units. Urination through air into a container is reported to produce only small changes $(0.02-0.03$ units) in urine $\mathrm{pH}$ as compared to collection under oil (Elliot et al., 1958). The $\mathrm{pH}$ values reported here are, therefore, quite close to the expected $\mathrm{pH}$ of the urine in the bladder immediately prior to micturition.

The mean hydrogen ion concentrations and urinary $\mathrm{pH}$ values for each day and each treatment are presented in Table 2 . The results of students' t-tests for differences among the mean hydrogen ion concentrations after the treatments are also given in Table 2. For all statistical analysis the $\mathrm{pH}$ values were converted to hydrogen ion concentrations for calculation of mean and standard deviation and the mean hydrogen ion concentration was then converted to the $\mathrm{pH}$ values shown in the tables. Although averaging of $\mathrm{pH}$ values has been commonly reported (Elliot et al., 1958; Gibaldi et al., 1974; Gibaldi et al., 1975; Henderson and Palmer, $1913 \mathrm{~b}$; Maslow, 1936; Levy and Lampton, 1975) it is not correct to do so as $\mathrm{pH}$ values are really the negative logarithm of the hydrogen ion concentration ${ }^{3}$. The urinary $\mathrm{pH}$ calculated from the mean hydrogen ion concentration may differ by as much as $0.42 \mathrm{pH}$ units from the number obtained by averaging $\mathrm{pH}$ values directly. It can be seen in Table 2 that differ-

\footnotetext{
2 Corning model 12 research pH meter.

3 The electrode actually measures activity, not concentration.
} 
Table 2. Comparison of mean urinary hydrogen ion concentration as a function of treatment and time

\begin{tabular}{|c|c|c|c|c|c|c|c|c|c|c|}
\hline \multirow[b]{2}{*}{ Day } & \multicolumn{4}{|c|}{ Treatment $\mathbf{A}$} & \multicolumn{4}{|c|}{ Treatment B } & \multicolumn{2}{|c|}{ Treatment A vs. Treatment B } \\
\hline & {$\left[\mathrm{H}^{+}\right]^{a}$} & $(\mathrm{pH})$ & $\mathrm{SD}^{\mathrm{b}}$ & $\mathbf{N}^{e}$ & {$\left[\mathrm{H}^{+}\right]$} & $(\mathrm{pH})$ & SD & $\mathbf{N}$ & Student $t$ & $\mathrm{p}-$ Value \\
\hline 1 & 2.18 & $(5.66)$ & 2.97 & 92 & 1.36 & $(5.87)$ & 2.20 & 97 & 2.16 & $0.0125<\mathrm{p}<0.025$ \\
\hline 2 & 2.09 & $(5.68)$ & 2.65 & 99 & 0.719 & $(6.14)$ & 1.31 & 107 & 5.37 & $p<0.0005$ \\
\hline 3 & 2.99 & $(5.52)$ & 4.10 & 101 & 0.538 & $(6.27)$ & 0.979 & 118 & 6.27 & $p<0.0005$ \\
\hline 4 & 2.48 & $(5.61)$ & 2.82 & 99 & 1.28 & $(5.89)$ & 2.18 & 106 & 3.42 & $p<0.0005$ \\
\hline \multirow[t]{3}{*}{5} & 3.95 & $(5.40)$ & 4.45 & 130 & 3.25 & $(5.49)$ & 7.26 & 148 & 0.955 & $\mathrm{NS}^{d}$ \\
\hline & \multicolumn{4}{|c|}{ Treatment $\mathrm{C}$} & \multicolumn{4}{|c|}{ Treatment B } & \multicolumn{2}{|c|}{ Treatment $C$ vs. Treatment $B$} \\
\hline & {$\left[\mathbf{H}^{+}\right]$} & $(\mathrm{pH})$ & SD & $\mathbf{N}$ & {$\left[\mathrm{H}^{+}\right]$} & $(\mathrm{pH})$ & $\mathrm{SD}$ & $\mathbf{N}$ & Student $\mathrm{t}$ & $\mathrm{p}$-Value \\
\hline 1 & 2.20 & $(5.66)$ & 2.47 & 93 & 1.36 & $(5.87)$ & 2.20 & 97 & 2.48 & $0.005<\mathrm{p}<0.01$ \\
\hline 2 & 1.77 & $(5.75)$ & 2.10 & 97 & 0.719 & (6.14) & 1.31 & 107 & 7.91 & $\mathrm{p}<0.0005$ \\
\hline 3 & 209 & $(5,68)$ & 2.61 & 98 & 0.538 & $(6.27)$ & 0.979 & 118 & 5.96 & $p<0,0005$ \\
\hline 4 & 2.66 & $(5.58)$ & 3.29 & 106 & 1.28 & $(5.89)$ & 2.18 & 106 & 3.61 & $\mathrm{p}<0.0005$ \\
\hline \multirow[t]{3}{*}{$\begin{array}{l}4 \\
5\end{array}$} & 3.00 & $(5.52)$ & 3.97 & 141 & 3.25 & $(5.49)$ & 7.26 & 148 & 0.514 & $\mathrm{NS}^{e}$ \\
\hline & \multicolumn{4}{|c|}{ Treatment A } & \multicolumn{4}{|c|}{ Treatment $\mathrm{C}$} & \multicolumn{2}{|c|}{ Treatment A vs. Treatment C } \\
\hline & {$\left[\mathrm{H}^{+}\right]$} & $(\mathrm{pH})$ & $\mathrm{SD}$ & $\mathbf{N}$ & {$\left[\mathrm{H}^{+}\right]$} & $(\mathrm{pH})$ & SD & $\mathbf{N}$ & Student $t$ & p-Value \\
\hline 1 & 2.18 & $(5.66)$ & 2.97 & 92 & 2.20 & $(5.66)$ & 2.47 & 93 & 0.0498 & $\mathrm{NS}^{\mathrm{e}}$ \\
\hline 2 & 2.09 & $(5.68)$ & 2.65 & 99 & 1.77 & $(5.75)$ & 2.10 & 97 & 0.935 & $\mathrm{NS}^{\mathrm{d}}$ \\
\hline 3 & 2.99 & $(5.52)$ & 4.10 & 101 & 2.09 & $(5.68)$ & 2.61 & 98 & 1.84 & $0.025<\mathrm{p}<0.05$ \\
\hline 4 & 2.48 & $(5.61)$ & 2.82 & 99 & 2.66 & $(5.58)$ & 3.29 & 106 & 0.419 & $\mathrm{NS}^{\mathrm{e}}$ \\
\hline 5 & 3.95 & $(5.40)$ & 4.45 & 130 & 3.00 & $(5.52)$ & 3.97 & 141 & 1.85 & $0.025<p<0.05$ \\
\hline
\end{tabular}

ences among treatments of $<0.25 \mathrm{pH}$ units are significant. Direct averaging of $\mathrm{pH}$ values also leads to incorrect $p$-values when comparing different treatments or groups of subjects. Incorrect averaging of $\mathrm{pH}$ values usually (but not always) leads to a falsely high level of significance between the urinary $\mathrm{pH}$ values of treatments being compared and often leads to a conclusion of $\mathrm{p}<0.05$ when correct calculation using hydrogen ion calculation gives $p>0.25$.

All urine hydrogen ion concentration values were combined from samples collected between 8:00 a.m. - 1:00 p.m., 1:00 p.m. - 6:00 p.m.; 6:00 p.m. $-11: 00$ p.m., and 11:00 p.m. $-8: 00$ a.m. for each collection day. These time intervals correspond to the beginning of each time period for antacid administration in treatment B (Table 1). The mean hydrogen ion concentration for each group of samples for treatments A, B and C are given in Table 3. The data are depicted graphically in Figure 1. Statistical comparisons of mean hydrogen ion concentrations among treatments $\mathrm{A}, \mathrm{B}$ and $\mathrm{C}$ are presented in Table 4.

\section{Discussion}

Chronic administration of the antacid did not change the shape of the circadian urinary $\mathrm{pH}$ curve although the entire curve was shifted in the alkaline direction (Fig. 1). This persistence of the diurnal excretory rhythm has also been observed in the presence of starvation, water deprivation, salt deprivation, temporary disturbance of the sleep rhythm or administration of antidiuretic hormone or deoxycortisone acetate (Stanbury and Thompson, 1951). These results are interesting since sodium bicarbonate is reported to maintain urine $\mathrm{pH}$ at approximately 8.0 to 8.7 (Maslow, 1936; Henderson and Palmer, 1914). This discrepancy in effect may be due to differences in antacid dosage, or to the antacids making the urine alkaline by different mechanisms, or to collection of insufficient urine samples to see the circadian effect after sodium bicarbonate administration. In future studies involving interactions between antacids and other drugs, it is recommended that the effect of the specific antacid involv- 
Table 3. Mean urinary hydrogen ion concentration and $\mathrm{pH}$ values for four daily dosage intervals

\begin{tabular}{|c|c|c|c|c|c|c|c|c|c|c|c|c|}
\hline \multirow[b]{2}{*}{ Dosage Interval } & \multicolumn{4}{|c|}{ Treatment A } & \multicolumn{4}{|c|}{ Treatment B } & \multicolumn{4}{|c|}{ Treatment C } \\
\hline & {$\left[\mathrm{H}^{+}\right]^{\mathrm{a}}$} & $(\mathrm{pH})^{\mathrm{b}}$ & $\mathrm{SD}^{c}$ & $(\mathrm{~N})^{\mathrm{d}}$ & {$\left[\mathrm{H}^{+}\right]$} & $(\mathrm{pH})$ & SD & $(\mathrm{N})$ & {$\left[\mathrm{H}^{+}\right]$} & $(\mathrm{pH})$ & SD & (N) \\
\hline \multicolumn{13}{|l|}{ Day 1} \\
\hline 8 a. m. -1 p.m. & 2.38 & $(5.62)$ & 3.19 & (24) & 1.99 & $(5.70)$ & 3.22 & (28) & 2.53 & $(5.60)$ & 2.30 & (28) \\
\hline 1 p.m. -6 p.m. & 2.24 & $(5.65)$ & 4.06 & (20) & 0.827 & $(6.08)$ & 1.49 & (26) & 2.18 & $(5.66)$ & 2.95 & (27) \\
\hline 6 p.m. -11 p.m. & 1.87 & $(5.73)$ & 1.81 & $(28)$ & 0.907 & $(6.04)$ & 1.26 & (25) & 2.01 & $(5.70)$ & 2.22 & (26) \\
\hline $\begin{array}{l}11 \text { p.m. }-8 \text { a.m. } \\
\text { Day } 2\end{array}$ & 2.59 & $(5.59)$ & 2.77 & (30) & 1.16 & $(5.94)$ & 1.50 & $(32)$ & 2.23 & $(5.65)$ & 2.27 & $(27)$ \\
\hline 8 a.m. -1 p.m. & 2.33 & $(5.63)$ & 2.84 & (23) & 0.790 & $(6.10)$ & 1.30 & (26) & 1.70 & $(5.77)$ & 1.93 & (23) \\
\hline 1 p.m. -6 p.m. & 2.35 & $(5.63)$ & 3.95 & $(22)$ & 0.468 & (6.33) & 1.15 & (23) & 1.09 & $(5,96)$ & 1.23 & (23) \\
\hline 6 p.m. -11 p.m. & 1.48 & $(5.83)$ & 1.56 & (26) & 0.537 & $(6.27)$ & 1.29 & (23) & 1.69 & $(5.77)$ & 2.43 & (22) \\
\hline $\begin{array}{l}11 \text { p.m. }-8 \text { a.m. } \\
\text { Day } 3\end{array}$ & 2.22 & $(5.65)$ & 2.07 & $(27)$ & 0.926 & $(6.03)$ & 1.33 & (33) & 2.04 & $(5.69)$ & 2.12 & (34) \\
\hline 8 a. m. -1 p. m. & 2.55 & $(5.59)$ & 2.81 & $(23)$ & 0.259 & $(6.59)$ & 0.376 & (24) & 2.36 & $(5.63)$ & 2.82 & (16) \\
\hline 1 p.m. -6 p.m. & 2.45 & $(5.61)$ & 3.40 & (25) & 0.230 & $(6.64)$ & 0.297 & $(28)$ & 2.42 & $(5.62)$ & 3.28 & (25) \\
\hline 6 p.m. -11 p.m. & 3.48 & $(5.46)$ & 6.14 & (24) & 0.597 & $(6.22)$ & 1.13 & (32) & 2.29 & $(5.64)$ & 2.75 & (24) \\
\hline $\begin{array}{l}11 \text { p.m. }-8 \text { a.m. } \\
\text { Day } 4\end{array}$ & 4.29 & $(5.37)$ & 3.97 & $(32)$ & 1.02 & $(5.99)$ & 1.83 & (33) & 3.13 & $(5.50)$ & 3.88 & (34) \\
\hline 8 a.m. -1 p.m. & 1.19 & $(5.92)$ & 1.54 & (16) & 1.76 & $(5.75)$ & 3.05 & (22) & 3.00 & $(5.52)$ & 3.37 & (19) \\
\hline 1 p.m. -6 p.m. & 1.51 & $(5.82)$ & 1.49 & (23) & 1.38 & $(5.86)$ & 2.41 & (20) & 1.61 & $(5.79)$ & 1.37 & (21) \\
\hline 6 p.m. -11 p. m. & 2.32 & $(5.63)$ & 2.12 & (23) & 0.945 & $(6.02)$ & 1.46 & (35) & 2.17 & $(5.66)$ & 3.27 & (35) \\
\hline $\begin{array}{l}11 \text { p. m. }-8 \text { a.m. } \\
\text { Day } 5\end{array}$ & 3.89 & $(5.41)$ & 3.72 & (39) & 2.06 & $(5.69)$ & 2.46 & $(27)$ & 3.35 & $(5.47)$ & 3.13 & (32) \\
\hline 8 a. m. -1 p.m. & 4.62 & $(5.34)$ & 5.44 & (29) & 4.00 & $(5.40)$ & 1.01 & $(38)$ & 3.95 & $(5,40)$ & 5.15 & (30) \\
\hline 1 p.m. -6 p.m. & 2.43 & $(5.61)$ & 3.21 & (23) & 3.79 & $(5.42)$ & 10.8 & $(27)$ & 2.21 & $(5.66)$ & 4.02 & (27) \\
\hline 6 p.m. -11 p.m. & 3.29 & $(5.48)$ & 5.23 & (24) & 2.26 & $(5.65)$ & 4.45 & (29) & 2.12 & $(5.67)$ & 2.67 & (22) \\
\hline $11 \mathrm{p}, \mathrm{m} .-8$ a.m. & 4.66 & $(5.33)$ & 4.33 & (25) & 3.12 & $(5.51)$ & 2.52 & (30) & 2.57 & $(5.59)$ & 3.62 & (36) \\
\hline
\end{tabular}

a Mean hydrogen ion concentration $\times 10^{-6}$

b pH corresponding to the mean hydrogen ion concentration.

- $\mathrm{SD}=$ standard deviation for the mean hydrogen ion concentration $\times 10^{-6}$.

d $\mathrm{N}=$ number of urine samples analyzed to obtain the mean and standard deviation.

Table 4. Statistical comparison of mean hydrogen ion concentration among treatments $A, B$ and $C$

\begin{tabular}{|c|c|c|c|}
\hline Dosage Interval & $\begin{array}{l}\text { Treatment A } \\
\text { vs. } \\
\text { Treatment B } \\
\text { p-Value }\end{array}$ & $\begin{array}{l}\text { Treatment A } \\
\text { vs. } \\
\text { Treatment C } \\
\text { p-Value }\end{array}$ & $\begin{array}{l}\text { Treatment B } \\
\text { vs. } \\
\text { Treatment C } \\
\text { p-Value }\end{array}$ \\
\hline \multicolumn{4}{|l|}{ Day 1} \\
\hline 8 a. m. -1 p.m. & $N S^{a}$ & $\mathrm{NS}^{\mathrm{a}}$ & $N S^{b}$ \\
\hline 1 p.m. -6 p.m. & $0.05<\mathrm{p}<0.1$ & $\mathrm{NS}^{\mathrm{a}}$ & $0.0125<p<0.025$ \\
\hline 6 p.m. -11 p. m. & $0.0125<p<0.025$ & $\mathrm{NS}^{\mathrm{a}}$ & $0.0125<p<0.025$ \\
\hline 11 p.m. -8 a.m. & $0.005<\mathrm{p}<0.01$ & $\mathbf{N S}^{\mathrm{a}}$ & $0.025<p<0.05$ \\
\hline \multicolumn{4}{|l|}{ Day 2} \\
\hline 8 a.m. -1 p.m. & $0.005<p<0.01$ & $N S^{b}$ & $0.025<\mathrm{p}<0.05$ \\
\hline 1 p.m. -6 p. m0.0.125<p<0.025 & $0.05<p<0.1$ & $0.025<\mathrm{p}<0.05$ & \\
\hline 6 p.m. -11 p.m. & $0.0125<p<0.025$ & $\mathrm{NS}^{\mathrm{a}}$ & $0.025<\mathrm{p}<0.05$ \\
\hline 11 p. m. -8 a.m. & $0.0005<p<0.0025$ & $\mathrm{NS}^{\mathrm{a}}$ & $0.005<\mathrm{p}<0.01$ \\
\hline \multicolumn{4}{|l|}{ Day 3} \\
\hline 8 a.m. -1 p.m. & $p<0.0005$ & $\mathrm{NS}^{\mathrm{a}}$ & $p<0.0005$ \\
\hline $1 \mathrm{p} . \mathrm{m} .-6 \mathrm{p} . \mathrm{m}$ & $0.0005<\mathrm{p}<0.0025$ & $N^{a}{ }^{a}$ & $p<0.0005$ \\
\hline 6 p.m. -11 p.m. & $0.005<\mathrm{p}<0.01$ & $N^{a}$ & $0.0005<p<0.0025$ \\
\hline 11 p. $m,-8$ a.m. & $p<0.0005$ & $\mathrm{NS}^{\mathrm{a}}$ & $0.0025<\mathrm{p}<0.005$ \\
\hline \multicolumn{4}{|l|}{ Day 4} \\
\hline 8 a.m. -1 p.m. & $\mathrm{NS}^{b}$ & $0.025<\mathrm{p}<0.05$ & $0.1<p<0.15$ \\
\hline 1 p.m. -6 p.m. & $\mathrm{NS}^{\mathrm{a}}$ & $\mathrm{NS}^{\mathrm{a}}$ & $\mathrm{NS}^{\mathrm{a}}$ \\
\hline 6 p.m. -11 p.m. & $0.0005<\mathrm{p}<0.0025$ & $\mathrm{NS}^{\mathrm{a}}$ & $0.0125<\mathrm{p}<0.025$ \\
\hline 11 p.m. -8 a.m. & $0.0125<\mathrm{p}<0.025$ & $\mathrm{NS}^{\mathrm{a}}$ & $0.025<p<0.05$ \\
\hline \multicolumn{4}{|l|}{ Day 5} \\
\hline 8 a.m. -1 p.m. & $N S^{a}$ & $\mathrm{NS}^{\mathrm{a}}$ & $N S^{a}$ \\
\hline 1 p.m. -6 p.m. & $\mathrm{NS}^{\mathrm{a}}$ & $\mathrm{NS}^{\mathrm{a}}$ & $\mathrm{NS}^{\mathrm{b}}$ \\
\hline 6 p. m. -11 p. m. & $\mathrm{NS}^{\mathrm{b}}$ & $\mathbf{N S}^{\mathbf{b}}$ & $\mathbf{N S}^{\mathrm{a}}$ \\
\hline 11 p.m. -8 a.m. & $0.05<p<0.1$ & $0.0125<\mathrm{p}<0.025$ & $\mathrm{NS}^{b}$ \\
\hline
\end{tabular}

NS $=p>0.25$.

- NS $=0.10<p<0.25$. 


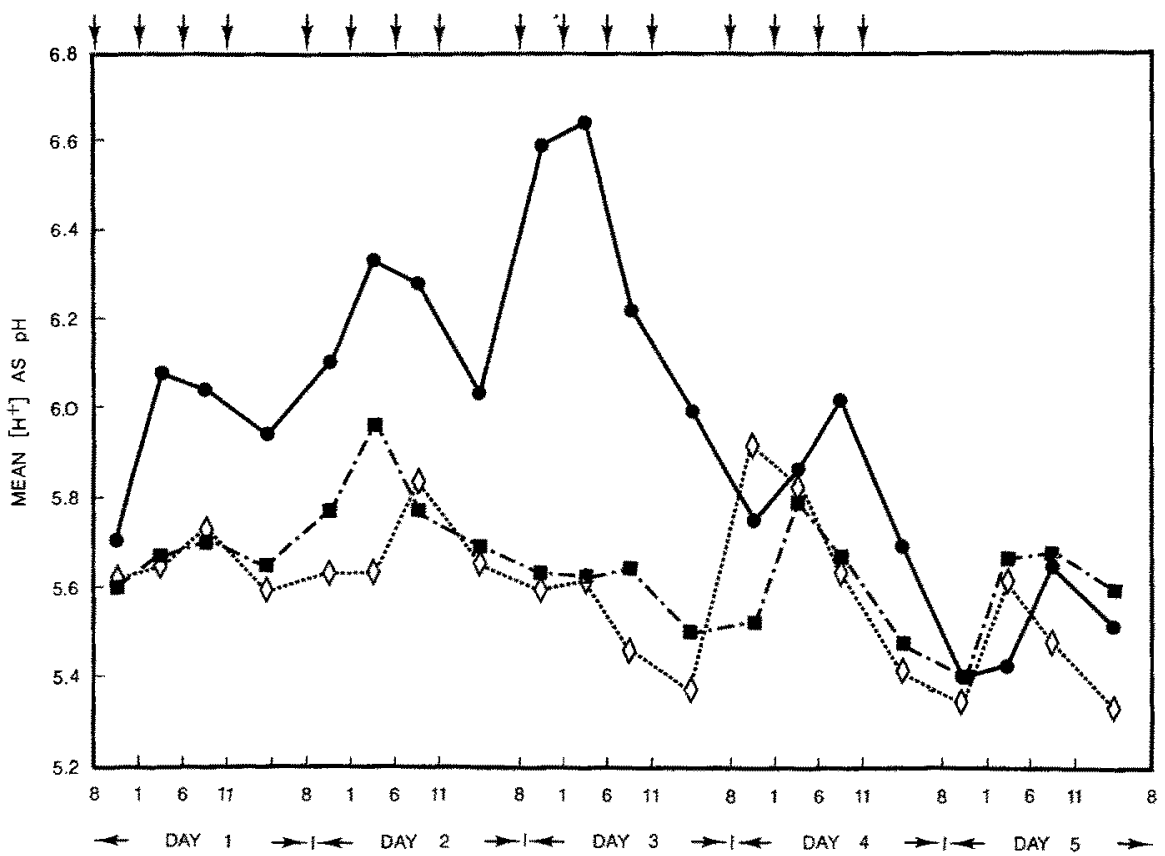

Fig. 1. Relationship of urinary $\mathrm{pH}$ and time after single and multiple doses of antacid. Each symbol represents the mean urinary $\mathrm{pH}$ for the time period involved (see Tables 4-6) and is plotted at the midpoint of the time period. Key: $\diamond$ treatment $A$ (no antacid); $\bullet$, treatment B (chronic antacid); $\mathbf{n}$, treatment $\mathrm{C}$ (single dose of antacid on day 4 ); $L$, indicates time of antacid dose for treatment $B$ only

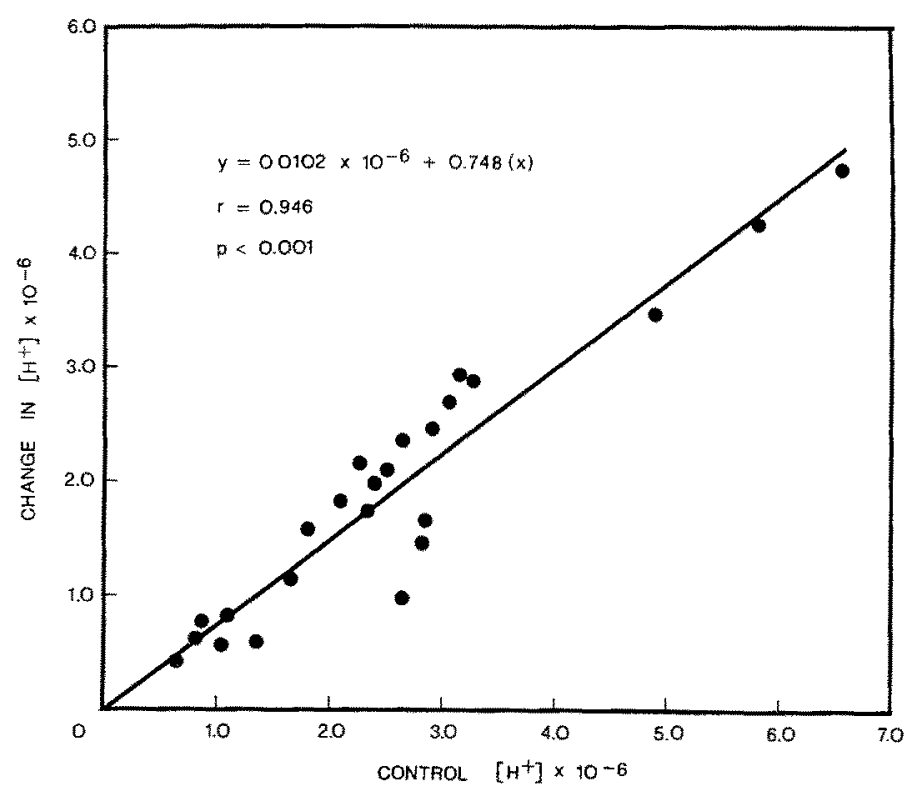

Fig. 2. Relationship between average change in hydrogen ion concentration for each subject for days 2 and 3 and average hydrogen ion concentration during the control period ed on circadian rhythm of urinary $\mathrm{pH}$ and interacting drug half-life be determined. For the aluminum and magnesium hydroxides antacid, the circadian rhythm of urinary $\mathrm{pH}$ predominates over the effect ot the antacid, particularly in the mid-afternoon to the middle of the night period where mean hydrogen ion concentration is rising and $\mathrm{pH}$ is falling, even though antacid was administered at $6: 00 \mathrm{p.m}$. and 11:00 p.m. It should be noted that individual urine $\mathrm{pH}$ time curves were highly variable in shape and not nearly as smooth as the mean curves in Figure 1. Two subjects, who were nocturnal work- ers, had urine $\mathrm{pH}$ time curves which were the exact inverse of the mean curve values for all 3 treatments.

The mean hydrogen ion concentration $(2.58$ $\times \cdot 10^{-6}, \mathrm{~S} . \mathrm{D} .=3.28 \times 10^{-6}, \mathrm{~N}=834$ ) for all of the control urines corresponded to a $\mathrm{pH}$ of 5.59 , which is about $0.4 \mathrm{pH}$ units less than the reported mean $\mathrm{pH}$ for urine obtained by averaging $\mathrm{pH}$ values from normal subjects (Elliot et al., 1958; Gibaldi et al,, 1974; Gibaldi et al., 1975; Maslow, 1936; Henderson and Palmer, 1914; Levy and Lampton, 1975). The maximum effect of the antacid on uri- 
nary $\mathrm{pH}$ occurred on day 3 as has been previously reported (Gibaldi et al., 1974). The difference between the mean urinary hydrogen ion concentration for chronic treatment with antacid on day $3(\mathrm{pH}$ $6.27)$ and the mean urinary hydrogen ion concentration for the subjects of treatment A on day $3(\mathrm{pH}$ 5.52 ) was $0.75 \mathrm{pH}$ units (Table 2). This compares with a reported difference of $0.86 \mathrm{pH}$ units after antacid administration when the more acidic nighttime urines were not included in the evaluation (Gibaldi et al., 1974).

Perusal of Table 2 reveals that the mean urinary $\mathrm{pH}$ value for each day was significantly higher when antacid was administered chronically (treatment B, days $1-4)$ than when no antacid was administered (treatment $A$ and days 1-3 of treatment $C$ ). Furthermore, when a single dose of antacid was given (day 4 , treatment $C$ ), the mean urinary hydrogen ion concentration remained significantly lower than day 4 of chronic antacid administration. There was, however, no significant difference between the mean urinary hydrogen ion concentrations for each of days 1,2 and 4 for treatments $A$ and $C$, which indicates that the single dose of antacid had little, if any, effect on urinary $\mathrm{pH}$.

Table 4 shows that chronic administration of antacid (treatment B) produced a significant decrease in urinary hydrogen ion concentration (increased $\mathrm{pH}$ ) for days 1-3 and the latter half of day 4 , compared with no antacid administration (treatment $\mathrm{A}$ ). The 8:00 a.m. - 1:00 p.m. and 1:00 p.m. $-6: 00$ p. m. mean urinary hydrogen ion concentrations on day 4 do not differ significantly for treatments $A$ and $B$; the reason for this is obscure. The mean urinary hydrogen ion concentration for day 4 is significantly lower $(p<0.0005)$ than that for day 3 after treatment $B$ which is not expected since antacid was administered throughout day 4 . The lower urinary $\mathrm{pH}$ for day 4 after treatment $\mathrm{B}$ cannot be explianed by overnight fasting as the urinary $\mathrm{pH}$ for day 4 versus day 3 increased after treatment $A$. Table 4 and Figure 1 show that the urinary hydrogen ion concentrations return to control values within $12 \mathrm{~h}$ after stopping the antacid treatment.

There was a significant linear relationship between the decrease in urinary hydrogen ion concentration, caused by chronic administration of aluminium and magnesium hydroxides suspension, and the initial urinary hydrogen ian concentration during a control period (Fig. 2). The correlation coefficient was $0.946(\mathrm{p}<0.001)$. The individual subject data for the 24 subjects of this study, together with the statistical evaluation, revealed no such significant trends when change in mean urinary $\mathrm{pH}$ and mean $\mathrm{pH}$ of control urines were evaluated.
The correlation coefficient for change in mean urinary $\mathrm{pH}$ after 2 days of antacid administration versus the mean control urine $\mathrm{pH}$ was -0.325 ; the correlation coefficient for change in mean urinary $\mathrm{pH}$ after 3 days of antacid administration versus the mean control urine $\mathrm{pH}$ was -0.052 ; neither of these correlation coefficients was significant. It should be noted that although correlations, such as shown in Figure 2, involving hydrogen ion concentrations, have a positive slope and correlation coefficient, analogous plots, based on $\mathrm{pH}$ have a negative slope and correlation coefficient, as formerly reported by Gibaldi et al. (1974).

\section{References}

Beckett, A.H., Rowland, M.: Rhythrnic urinary excretion of amphetamine in man. Nature 204, 1203-1204 (1964)

Beckett, A.H., Rowland, M., Turner, P.: Influence of urinary pH on excretion of amphetamine. Lancet 1965/I, 303

Burnett, G.D., Blume, F. E.: Alkaline tides. J. Clin. Invest. 17, 159-165 (1938)

Dettli, L., Spring, P.: Diurnal variations in the elimination rate of a sulfonamide in man. Helv. Med. Acta 33, 291-306 (1966)

Elliot, J.S., Sharp, R.F., Lewis, L.: Urinary pH. J. Urol. 81, 339-343 (1958)

Gibaldi, M., Grundhofer, B., Levy, G.: Effect of antacids on $\mathrm{pH}$ of urine. Clin. Pharmacol. Ther. 16, 520-525 (1974)

Gibaldi, M., Grundhofer, B., Levy, G.: Time course and dose dependence of antacid effect on urine pH. J. Pharm. Sci. 64, 2003-2004 (1975)

Henderson, L.J., Palmer, W. W.: On the extremes of variation of the concentration of ionized hydrogen in human urine. J. Biol. Chem. 14, 81-85 (1913a)

Henderson, L.J., Palmer, W.W.: On the intensity of urinary acidity in normal and pathological conditions. J.Biol. Chem. 13, 393-405 (1913 b)

Henderson, L. J., Palmer, W. W.: On the several factors of acid excretion. J. Biol. Chem. 17, 305-315 (1914)

Jones, H.B.: On the variations of the acidity of the urine in the state of health. Philos. Trans. R. Soc..(London) 135, 335 (1845)

Levy, G., Lampton, T.: Relationship between $\mathrm{pH}$ of saliva and pH of urine. J. Pharm. Sci. 64, 890-891 (1975)

Maslow, L. A.: A study of the hydrogen ion concentration and crystallography of normal urine. J. Urol. 35, 674-6S0 (1936)

Mills, J.N., Stanbury, S.W.: Intrinsic diumal rhythm in urinary electrolyte output. J. Physiol. 115, 18P-19P (1951)

Stanbury, S.W., Thompson, A.E.: Diurnal variations in electrolyte excretion. Clin. Sci. 10, 267-293 (1951)

Received: July 4, 1977, in revised form: September 13, 1977 accepted: September 27, 1977

Dr. John G. Wagner

Upjohn Center for Clinical

Pharmacology

The University of Michigan

Medical Center

Ann Arbor, Michigan 48109, USA 